\title{
Anemia Pada Remaja Putri Dan Pentingnya Mengkonsumsi Tablet Fe Pada Remaja Di SMK 2 Mei Pringsewu
}

\author{
Analia Kunang \\ Program Studi D III Kebidanan, Fakultas Kesehatan, Universitas Muhammadiyah Pringsewu \\ analiakunang@umpri.ac.id
}

\begin{abstract}
Abstrak
Anemia gizi disebabkan oleh kekurangan zat gizi yang berperan dalam pembentukan hemoglobin, baik karena kekurangan konsumsi atau karena gangguan absorpsi . zat gizi yang bersangkutan adalah besi, protein, piridoksin (vitamin B6). Tujuan dari kegiatan ini untuk memberi pengetahuan pada remaja putri untuk pentingnya mengkonsumsi tablet penambah darah untuk persiapan kehamilan dan persalinan. Anemia pada remaja akan berdampak buruk seperti kurangnya konsentrasi, kebugaran imunitas dan produktifitas. Remaja putri mengalami menstruasi setiap bulannya yang menyebabkan banyak mengeluarkan darah sehingga rentan sekali mengalami anemia. Anemia akan berdampak buruk jika tidak ditangani dengan segera mengingat remaja putri adalah calon ibu yang akan hamil dan melahirkan seorang bayi. Metode yang digunakan dengan cara ceramah dan demontrasi memberikan pengetahuan pentingnya mencegah anemia pada remaja dan mengkonsumsi tablet Fe pada remaja.
\end{abstract}

Kata kunci : Anemia, Remaja,Tablet zat besi

\begin{abstract}
Nutritional anemia is caused by a deficiency of nutrients that play a role in the formation of hemoglobin, either due to lack of consumption or absorption problems. the nutrients concerned are iron, protein, pyridoxine (vitamin B6). The purpose of this activity is to provide knowledge to young women about the importance of consuming blood booster tablets in preparation for pregnancy and childbirth. Anemia in adolescents will have a negative impact such as lack of concentration, immune fitness and productivity. Teenage girls experience menstruation every month which causes them to bleed a lot, making them very prone to anemia. Anemia will have a bad impact if it is not treated immediately considering that young women are prospective mothers who are about to become pregnant and give birth to a baby. The method used by lectures and demonstrations provides knowledge on the importance of preventing anemia in adolescents and consuming Fe tablets in adolescents.
\end{abstract}

Keywords: Anemia, Teenagers, iron tablets

\section{PENDAHULUAN}

Anemia merupakan salah satu masalah kesehatan masyarakat di Indonesia yang dapat dialami oleh semua kelompok umur mulai dari balita sampai usia lanjut. Riskesdas 2013 menunjukkan bahwa prevalensi anemia pada perempuan usia $\geq 15$ tahun sebesar $22,7 \%$ sedangkan prevalensi anemia pada ibu hamil sebesar $37,1 \%$. Banyak remaja putri di Indonesia mengalami anemia yang disebabkan oleh kurangnya zat besi dalam tubuh. Anemia salah satu

http://ejournal.urindo.ac.id/index.php/PAMAS

Article History :

Submitted 16 Februari 2021, Accepted 28 April 2021, Published 30 April 2021 
penyebab masalah kesehatan yang menyebabkan kurangnya Hemoglobin atau sel darah merah dalam tubuh. Sedangkan sel darah merah sangat penting bagi tubuh manusia sebagai pengangkut oksigen keseluruh tubuh manusia. Penyebab dari anemia pada remaja putri adalah terjadinya menstruasi setiap bulannya yang menyebabkan kehilangan darah, penyebab lain adalah diet ketat yang sering dilakukan oleh remaja putri untuk menunjang penampilan sehingga mengabaikan mengkonsumsi makanan yang mengadung zat besi yang tinggi.

Dikutip dari World Health Organization (WHO,2015) menyebutkan 30\% banyak ibu hamil dan remaja putri mengalami kekurangan sel darah merah. Remaja putri yang mengalami anaemia mencapai angka 29\%. Prevalensi anemia di Indonesia secara nasional mencapai $21,7 \%$, dengan penderita anemia pada usia $5-14$ tahun sebesar $26,4 \%$ dan $18,4 \%$ penderita pada usia 15-24 tahun. Sedangkan berdasarkan jenis kelamin didapatkan bahwa proporsi anemia pada perempuan lebih tinggi (22,7\%) 2 dibandingkan pada laki-laki (12,4\%). Anemia menjadi masalah kesehatan karena prevalensinya >20\% (Riskesdas, 2013).

Pada remaja putri yang mengalami kekurangan sel darah merah akan menyebabkan fungsi kognitif menurun sehingga menyebabkan proses penerimaan informasi terhambat dan membuat konsentrasi belajar menurun. Anemia yang berkepanjangan akan berdampak serius pada remaja putri pasalnya remaja putri adalah calon seorang ibu yang akan melahirkan bayi, dan akan beresiko mengalami BBLR, Stunting, melahirkan bayi premature dan perdarahan saat melahirkan. Kekurang sel darah merah pun akan meningkatkan resiko darah tinggi dan biasanya penyakit jantung pada bayi yang akan dilahirkan (Susetyawati,2016)

Manfaat mengkonsumsi tablet penambah darah pada remaja putri untuk menggantikan zat besi akibat terjadinya datang bulan di setiap bulannya. Selain itu, strategi penanggulangan anemia pada ibu hamil juga akan lebih efektif jika dilakukan sejak masa remaja (Irianto, 2014)

\section{METODE}

Penggunaan metode ceramah dan demonstrasi, memberikan pengetahuan pentingnya mencegah anemia pada remaja dan menkonsumsi tablet Fe pada remaja. Melakukan pendampingan mengkonsumsi tablet Fe pada remaja putri. Pada tahapan perencanaan Kegiatan ini dimulai dari dengan melakukan prasurvey tempat untuk pelaksanaan kegiatan, menetapkan sasaran yaitu seluruh remaja putri di SMK 2 Mei. Kemudian melakukan pembuatan proposal dan pengajuan dana $70 \%$ untuk kelancaran proses kegiatan, melakukan penyelesaian perizinan tempat/lokasi yang akan dilakukan kegiatan pengabdian pada 
masyarakat. Kegiatan ini beranggotakan 6 panitia terdiri dari 2 dosen beserta mahasiswi kebidanan, dan remaja putri yang mengikuti kegiatan ini berjumlah 33 siswi, rata - rata siswi berumur 16- 19 tahun. Pada kegiatan selanjutnya yang sudah ditentukan waktunya, pada tahap ini pengabdi berkoordinasi dengan Pihak SMK 2 Mei Pringsewu. maka Selanjutnya pengabdi mempersiapkan kegiatan penyuluhan berupa materi tentang anemia pada remaja dan pentingnya mengkonsumsi tablet Fe pada remaja dengan media yang digunakan (leaflet) dan diakhir acara panitia bersama remaja putri bersama - sama mengkonsumsi tablet Fe. Pada tahap pelaksanaan ini diberikan informasi tentang anemia pada remaja sebelum diberikan materi yang melibatkan semua unsur dalam kegaitan pengabdian masyarakat, kegiatan ini diharapkan bertambahnya pengetahuan remaja putri tentang bahaya anemia pada remaja serta meningkatkan kepatuhan remaja putri untuk mengkonsumsi tablet Fe. Sehingga dapat diukur setelah kegiatan selesai dengan cara melakukan tanya jawab tentang bahaya anemia pada remaja serta komitmen para remaja putri untuk terus mengkonsumsi tablet penambah darah setiap bulan nya mengingat dampak jangka panjang yang akan terjadi pada remaja yang mengalami anemi

Gambar kegiatan pengabdian masyarakat para siswi SMK 2 Mei Pringsewu mengkonsumsi tablet Fe

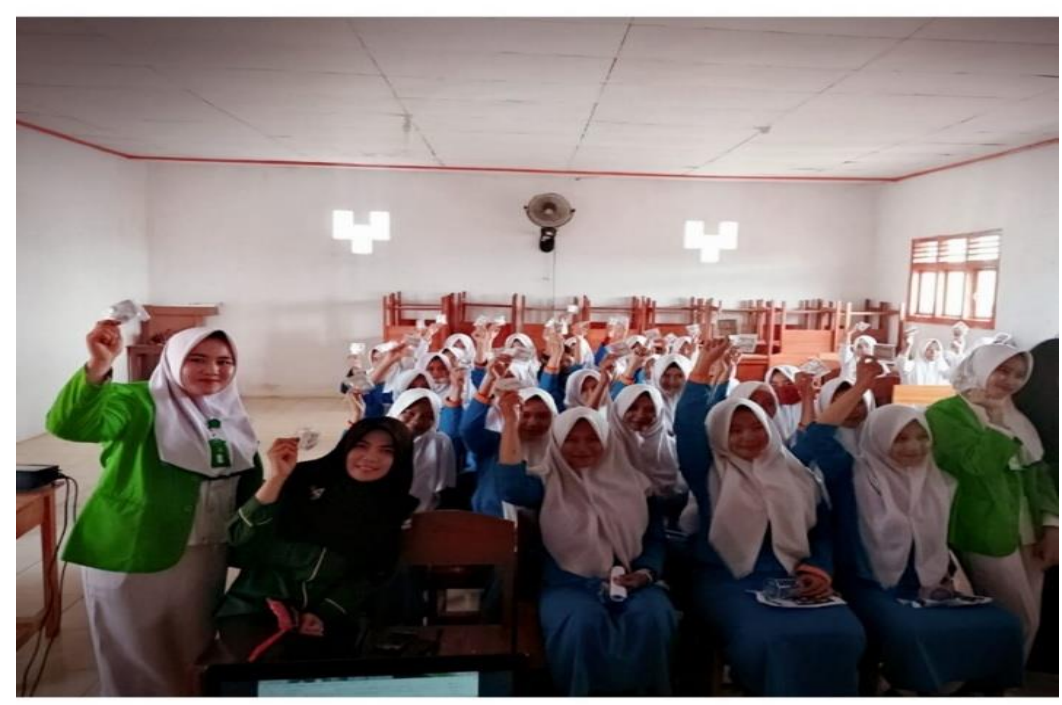

\section{HASIL DAN PEMBAHASAN}

Pelaksanaan kegiatan ini membutuhkan bantuan dari pihak sekolahan dan komitmen para remaja putri untuk mengkonsumsi tablet Fe, kegiatan ini membutuhkan waktu 1 bulan 
untuk merancang, melaksanakan dan mengevaluasi kegiatan yang dilaksanakan. Beberapa hal yang perlu dibahas dalam hasil pengabdian ini, yaitu motivasi remaja putri untuk mengkonsumsi tablet karena mengaggap tidak pentingnya mengkonsumsi tablet penambah darah. Selanjutnya adalah antusias para peserta setelah mendapatkan materi meningkat, dan mereka berjanji untuk mengkonsumsi tablet $\mathrm{Fe}$, mereka menyimak materi dengan baik dengan terjadinya tanya jawab antar penceramah dengan remaja putri. Saat kegiatan berlangsung, ada beberapa kendala seperti remaja putri yang sulit untuk mengikuti kegiatan, namun masalah tersebut dapat diselesaikan dengan mengarahkan siswi tersebut secara perlahan dan membutuhkan proses perhatian yang menarik untuk siswi ikut dalam kegiatan pengabdian masyarakat ini.

Hasil penelitian yang dilakukan Ikhmawati (2013), dengan hasil uji $\mathrm{P}=0,233$ berarti tidak ada hubungan yang signifikan antara pengetahuan tentang anemia terhadap kadar hemoglobin. Tidak adanya hubungan yang bermakna pada penelitian ini dikarenakan pengetahuan tentang anemia gizi besi diperoleh dalam proses belajar di sekolah. Pengetahuan yang didapat dalam proses pembelajaran wajib dirasa kurang dapat dipahami oleh sampel sehingga belum dapat mengubah sikap dan tindakan ke arah perilaku sehat dalam mencegah anemia. Menurut Maryani, kepatuhan merupakan salah satu faktor yang dianggap paling berpengaruh dalam keberhasilan program suplementasi besi. Kepatuhan mengonsumsi TTD diukur dari ketepatan jumlah tablet yang dikonsumsi dan frekuensi mengonsumsi tablet (Oktania, 2014). Remaja dikatakan patuh jika mengonsumsi tablet $\geq 75 \%$ dari jumlah tablet besi yang seharusnya dikonsumsi (Nuradhiani, 2017).

Anemia bisa terjadi karena adanya penurunan kadar hemoglobin dalam darah atau eritrosi. Anemia pada remaja terjadi karena kurangnya asupan zat besi pada makanan yang dikonsumsi dan juga disebabkan karena terjadinya menstruasi setiap bulannya. Apabila jumlah simpanan zat besi berkurang danjumlah zat besi dalam tubuh, akibatnya kadar hemoglobin menurun di bawah normal yang disebut sebagai anemia gizi besi. Kebutuhan zat besi juga mengalami peningkatan pada remaja putri hingga $1,4 \mathrm{mg}$ pada saat haid berlangsung(Gibney, 2008). Anemia pada remaja dapat dicegah dengan cara mengkonsumsi tablet penambah darah yang bisa diminum secara teratur oleh remaja selama datang bulan. Pemberian suplemen zat besi akan meningkatkan hemoglobin darah ratarata 10,2 g/L pada wanita hamil dan 8,6 g/L pada wanita tidak hamil. Sekitar $50 \%$ dari anemia pada wanita bisa dihilangkan dengan suplementasi zat besi. Hal ini sejalan dengan penelitian yang dilakukan oleh Ahmady, dkk (2016) dengan intervensi yang dilakukan pada responden untuk 
mengkonsumsi tablet Fe bahwa hasil uji statistik menunjukkan nilai $(p=0.000)$ yang bearti adanya perbedaan kadar $\mathrm{Hb}$ sebelum dan sesudah intervensi pada kelompok perlakuan. Hasil uji statistik didapatkan bahwa dalam penelitian ini terdapat pengaruh konsumsi tablet Fe terhadap peningkatan kadar hemoglobin pada remaja putri di SMA 2 Ngaglik Sleman. Penelitian ini menunjukkan bahwa ada peningkatan kadar hemoglobin setelah mengkonsumsi tablet Fe. Intervensi yang diberikan pada responden dengan mengkonsumsi tablet Fe sangat membantu untuk menanggulangi anemia zat besi.

\section{SIMPULAN}

Kegiatan ini berbentuk laporan hasil berupa peningkatan pengetahuan remaja putri terkait bertambahnya pengetahuan tentang pentingnya mengkonsumsi tablet Fe Keberhasilan ini dapat dilihat dari :

1. Terjadinya Tanya jawab antara pemateri dengan remaja putri, remaja putri mampu menjelaskan kembali materi yang sudah diberikan serta mengerti tentang dampak yang terjadi remaja putri yang terkena anemia

2. Adanya respon yang positif dan antusias para siswi terhadap kegiatan ini

3. $90 \%$ peserta mengikuti kegiatan dengan baik dan meningkatkan pengetahuan remaja tentang pentingnya mengkonsumsi tablet penambah darah untuk mencegah terjadi nya anemia pada remaja

4. Semua remaja putri mengkonsumsi tablet Fe bersama - sama dan berkomitmen akan mengkonsumsi tablet Fe setiap bulan nya.

\section{DAFTAR PUSTAKA}

Ikhmawati, Y., Sarbini, D., \& Dyah, S. (2013). Hubungan Antara Pengetahuan Tentang Anemia Dan Kebiasaan Makan Terhadap Kadar Hemoglobin Pada Remaja Putri Di Asrama SMA MTA Surakarta. Prodi Gizi Ilmu Kesehatan UniversitasMuhammadiyahSurakarta.

Nuradhiani, Annisa. 2017. Dukungan Guru Meningkatkan Kepatuhan Tablet Tambah Darah pada Remaja Putri Di Kota Bogor. J Gizi Pangan.12.3. 153-160. http://iournal.ipb.ac.id/index.php/igizipangan

Oktania, Siska. 2014. Faktor-faktor yang Mempengaruhi Kepatuhan Konsumsi Tablet Tambah Darah. Skripsi. Fakultas Farmasi. UMP. Palembang 
Permata, Hesti. 2018. Anemia Gizi Pada Remaja Putri Di Wilayah Kebupaten Banyumas. Jurnalkesmasindo.

Permatasari, Tyas. 2018. Efektifitas Program Suplementasi Zat Besi Pada Remaja Putri Di Kota Bogor. Jurnal MKMI. Vol 14. 1.

Raptauli, Nahsty. 2012. Faktor Yang Berhubungan Dengan Status Anemia Pada Remaja Putri Di Kota Depok. Skripsi. Fakultas Kesehatan Masyarakat. Universitas Indonesia 